Devices 


\section{CUISINART FOR CLEANING ELDERBERRY (SAMBUCUS SPP. L. [CAPRIFOLIACEAE]) SEEDS}

Michelle Truscott |

A B STRACT

The common food processor is an effective tool for cleaning elderberry (Sambucus spp. L. [Caprifoliaceae]) seeds. Seeds cleaned with this device can be stored in the refrigerator for years without developing mold.

KEY WORDS seed cleaning

NOMENCLATURE USDA NRCS (2002)

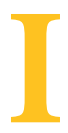

prefer using a food processor, the kitchen Cuisinart (Model DFP Deluxe 11), for cleaning seeds of elderberry (Sambucus spp. L. [Caprifoliaceae]). At Cornflower Farms, we collect Sambucus berries in the wild at site-specific locations throughout California. Once we get the berries back to the nursery, we remove them by hand from the stems as the first step in the seed cleaning process. Then we add the berries to the food processor (Figure 1). Depending on how juicy the berries are, we may or may not need to add water. If the berries clump to the sides of the processor, we add enough water to ensure they swirl.

We run the food processor for about 1 min until we have a puree of berries. The puree is poured into a clean, empty bucket and then we slowly add water (Figure 2). Viable seeds sink to the bottom of the bucket while voided seeds and pulp float to the surface. The waste is decanted off the top and we keep repeating the process until we are left with clean seeds at the bottom of the bucket. The reason we pulled the berries off the stems is that otherwise the food processor chops the stems into little pieces that sink to the bottom of the bucket with the clean seeds. Once clean, we drain off all of the water and place the seeds on newspaper to surface dry (Figure 3), which may take 1 to $4 \mathrm{~d}$ depending on temperature and relative humidity. This process cleans seeds so well they can be stored in a refrigerator for 6 to $8 y$ without mold problems. Also, we found that seeds cleaned with the food processor are less likely to mold and rot during the 3-mo cold, moist stratification period necessary for germination.

REFERENCE

USDA NRCS. 2002. The PLANTS database, version 3.5. URL: http://plants.usda.gov (accessed 14 Aug 2003). Baton Rouge (LA): The

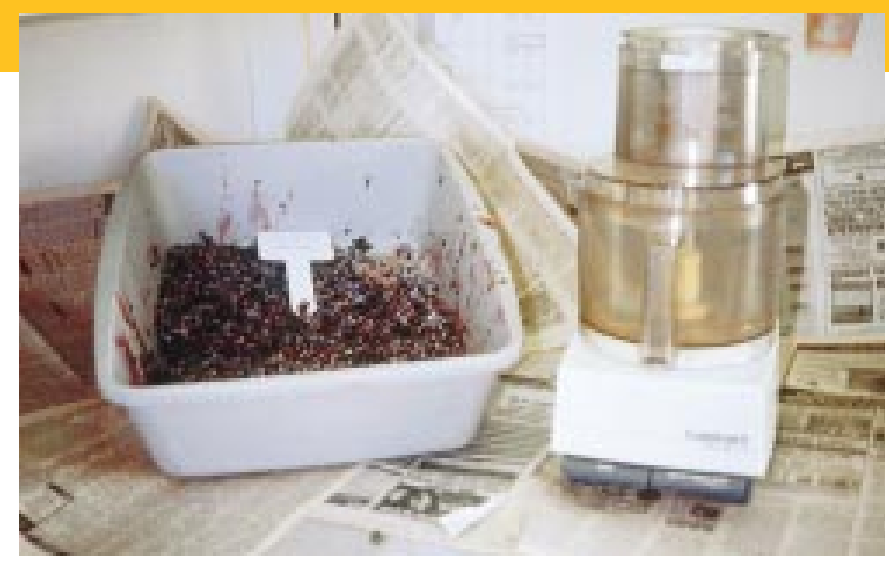

Figure 1. Elderberry fruits ready for cleaning and my trusty food processor.

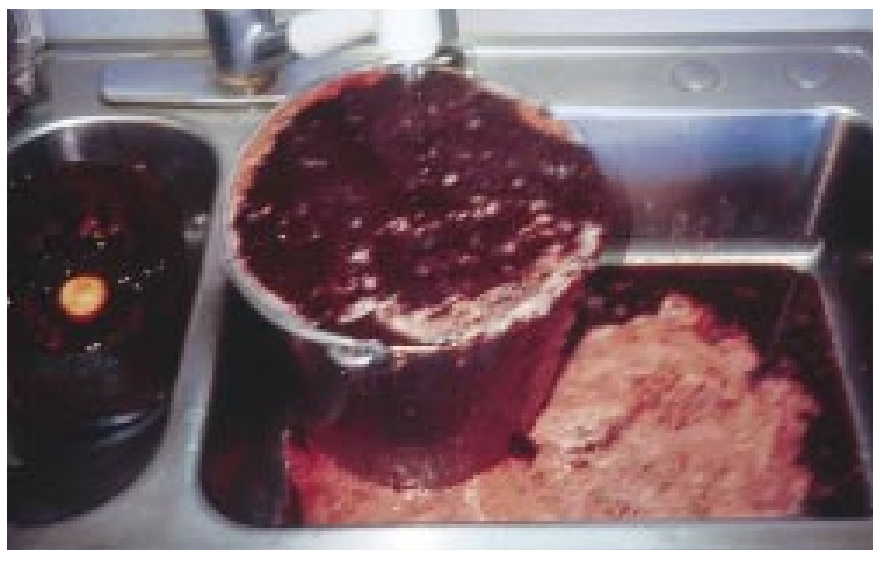

Figure 2. Floating the debris away from clean seeds.

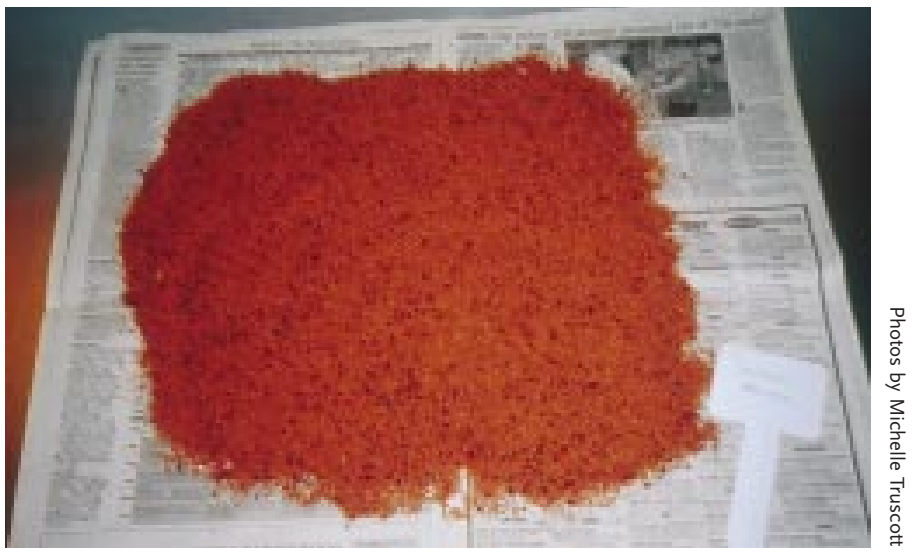

Figure 3. Clean elderberry seeds ready for storage.

\section{AUTHOR INFORMATION}

Michelle Truscott, Grower

Cornflower Farms Inc

PO Box 896 | Elk Grove, CA 95759

michelle@cornflowerfarms.com 
BLENDING DRY SEEDS CLEAN

Joseph D Scianna |

A B STRACT A kitchen blender with a slow-speed pulse button has been used to clean small volumes of a variety of seeds.

KEY WORDS seed cleaning, Asteraceae, Poaceae, Rosaceae, Ranunculaceae, Onagraceae, Liliaceae

NOM EN CLATURE USDA NRCS (2002)

\section{$\Lambda$} $\mathrm{t}$ the Plant Materials Center in Bridger, Montana, we process and clean more than 300 wildland seed collections annually, many consisting of small volumes of seedheads yielding less than $10 \mathrm{~g}(0.35 \mathrm{oz})$ of bulk seeds. If the seeds contain awns, wings, or other appendages requiring removal, or if the seeds are held tightly in the seedheads, the small volume of material cannot be adequately threshed in our hammermill. Manual processing of small volumes on a rubbing board is labor intensive and time consuming. To improve efficiency, we have developed a simple procedure using a conventional household blender.

Our technique begins with wrapping the impeller blades of the blender with duct tape to minimize seed damage. We wrap the blades so that the tape does not unravel or fray during use, but do not use so much tape that the impellers vibrate during operation, or bind with seeds and stems during processing. We recently became aware that coating the impeller blades with liquid plastic in lieu of duct tape has been used successfully in similar applications (Thomas 2003). An important feature of the blender is a low-speed pulse button, or other control that reduces impeller speed. The standard on:off low-speed setting on most blenders is too fast for seed processing.

By intermittently "pulsing" the low-speed setting, we control the duration and intensity of processing. Another important factor is the amount of seeds or seedheads initially placed in the blender. Too little material requires the addition of rice hulls or other inert material to create adequate abrasion. Too much material results in excessive maceration near the impellers, with little or no abrasion toward the top of the blender. The ideal amount of material to place in a blender varies with its size, but we find that $25 \%$ to $33 \%$ of storage capacity works well. Frequent inspection during processing is critical to assure that the seeds are not being damaged. Final
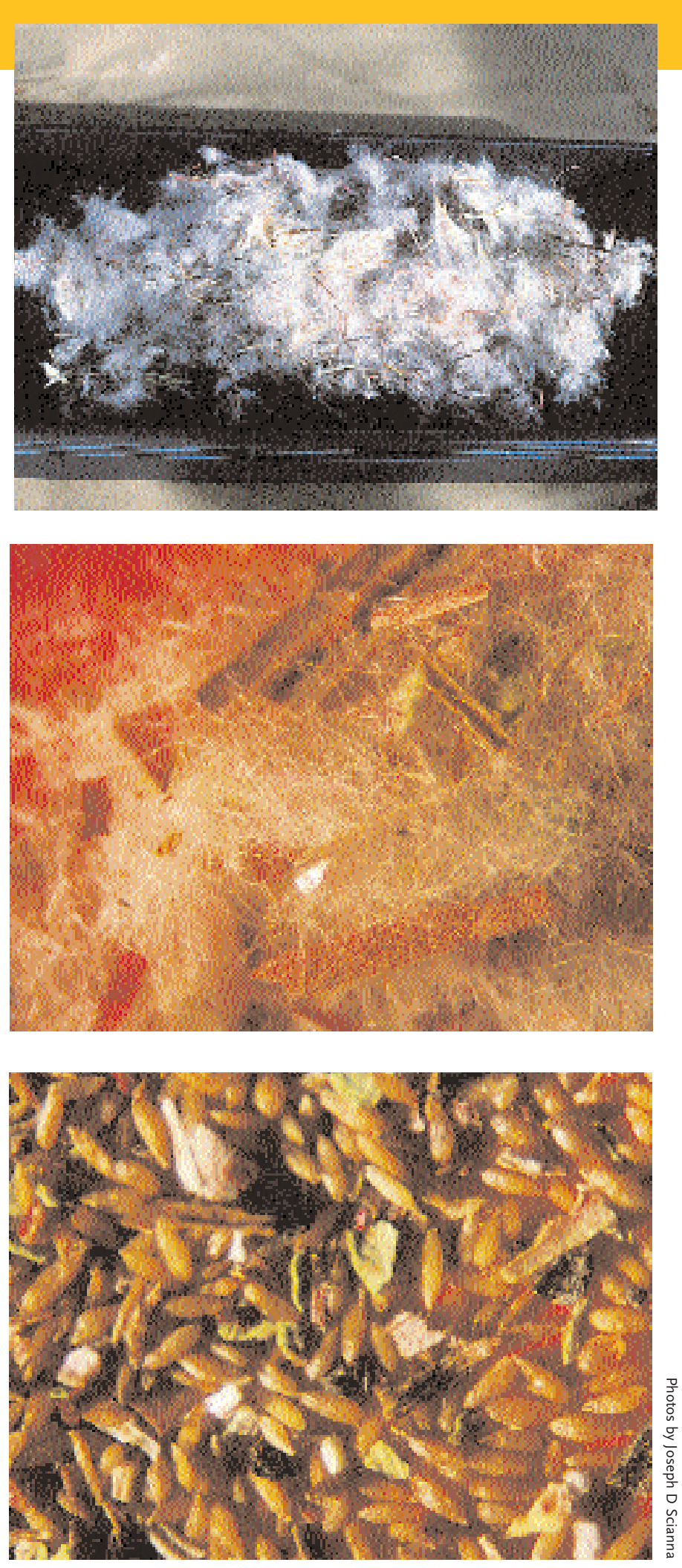

Using the blender, the extremely small seeds of fireweed (Chamerion angustifolium (L.) Holub ssp. angustifolium) collected in the field (top) can be extracted from the hair and other debris (bottom). 
cleaning is by sieving and winnowing or processing over a small fanning mill.

We use this technique successfully on many genera of the Asteraceae including pearly everlasting (Anaphalis spp. DC.), arnica (Arnica spp. L.), balsamroot (Balsamorhiza spp. Nutt.), daisy (Erigeron spp. L.), blanket flower (Gaillardia spp. Foug.), golden aster (Heterotheca spp. Cass.), goldenrod (Solidago spp. L.), and aster (Symphyotrichum spp. Nees). We have also used it with feathery achenes of Geum L. spp. (Rosaceae) and Pulsatilla P. Mill. spp. (Ranunculaceae), winged seeds of pines (Pinus spp. L. [Pinaceae]) and Douglas-fir (Pseudotsuga menziesii (Mirbel) Franco [Pinaceae]), and grass seeds (Poaceae) such as needlegrass (Achnatherum spp. Beauv.), wheatgrass (Pseudoroegneria spp. (Nevski) A. Löve), and wildrye (Elymus spp. L.). It also works well with dehiscent capsules of willowherbs (Epilobium spp. L. [Onagraceae]) and glacier lily (Erythronium spp. L. [Liliaceae]).

\section{REFERENCES}

Thomas D. 2003. Modifying blender blades for seed cleaning. Native Plants Journal 4:72-73.

USDA NRCS. 2002. The PLANTS database, version 3.5. URL: http://plants.usda.gov (accessed 20 Jun 2003). Baton Rouge (LA): The National Plant Data Center.

\section{AUTHOR INFORMATION}

Joseph D Scianna

Horticulturist

USDA Natural Resources Conservation Service

Bridger Plant Materials Center

Route 2 Box 1189

Bridger, MT 59014

Joe.Scianna@mt.usda.gov

\section{COLLECTING SEEDS FROM SOUTHEASTERN US WOODLAND SPECIES}

Barry Glick |

A B STRACT

In order to collect seeds from a wide range of southeastern US woodland species with diverse dispersal strategies, specially made collection bags are placed over plants. After collection, seeds are separated from debris with a strainer and further cleaned with a fanning mill. This method can be used for efficient collection of large numbers of seeds at ideal ripeness, in a nursery or in the wild.

\section{KEY WORDS} seed dispersal, Geranium maculatum, Jeffersonia diphylla, Viola species, Mitella species, Sanguinaria canadensis, Hepatica americana, Asarum canadense, Dicentra cucullaria, Dodecatheon species, Spiranthes cernua, Tipularia discolor

NOMENCLATURE USDA NRCS (2002)

grower cannot be in all places at all times, especially when producing and collecting seeds from hundreds of species. Ripening seeds are a temperature dependent phenomena, and this is further complicated by each species having its own prolonged period of fruit maturation and dispersal strategy. At Sunshine Farms and Gardens, we collect seeds and grow many of the most desired southeastern US woodland species. Many of these species can be challenging to collect seeds from due to unique dispersal mechanisms of the fruits or dispersal agents or simply due to the small size of the seeds and fruits. We have come up with an efficient and effective method to address this challenge.

Southeastern woodland species are as diverse in their dispersal strategies and fruits as in their wide range of attractive flowers and growth forms. Spotted geranium (Geranium maculatum L. [Geraniaceae]) is a classic example of explosive dehiscence, where the seeds are spring loaded and catapulted away from the plant when the fruits mature and split along the sutures. Twinleaf (Jeffersonia diphylla (L.) Pers [Berberidaceae]) produces a unique seed pod that resembles a hooded pouch with a lid at the top that opens with a hinge-like attachment when mature. Similarly, several violets (Viola spp. L. [Violaceae]) have small pods that explode upon maturation.

Alternatively, seeds may be dispersed by an external force such as raindrops, which disseminate the tiny black seeds of 
miterwort (Mitella spp. L. [Saxifragaceae]) from the opened saucer-shaped capsules. Ants are also important dispersal agents in woodlands and rapidly carry away the seeds of bloodroot (Sanguinaria canadensis L. [Papaveraceae]), Canadian wild ginger (Asarum canadense L. [Araceae]), American hepatica (Hepatica nobilis Schreb. var obtusa (Pursh) Steyermark [Ranunculaceae]) and Dutchman's breeches (Dicentra cucullaria (L.) Bernh. [Fumariaceae]).

Shooting star (Dodecatheon spp. L. [Primulaceae]) and Virginia bluebells (Mertensia virginica (L.) Pers. ex Link [Boraginaceae]) have capsules that open quickly upon maturation, while native orchids (Orchidaceae), such as nodding ladies tresses (Spiranthes cernua (L.) L.C. Rich) and cranefly orchid (Tipularia discolor (Pursh) Nutt.), have dust-like seeds that are dispersed immediately. Such small seeds and fruits can also be difficult or time consuming to collect seeds from.

In order to collect seeds from such a wide range of species, we have designed specially made collection bags that we place over our stock plants in the nursery as seeds approach maturation. The bags are made from a mill-spun polyester fiber that is rot and UV resistant and last for many years. Bags are available in $1.2 \times 1.8 \mathrm{~m}(4 \times 6 \mathrm{ft}), 1.2 \times 2.4 \mathrm{~m}(4 \times 8 \mathrm{ft})$ and $1.2 \times 3 \mathrm{~m}$ $(4 \times 10 \mathrm{ft})$ sizes from our nursery. We tie the bags over stock plants as the fruits are maturing and include a couple of marbles to help weigh them down.

After collection, seeds are passed through a metal strainer to separate seeds from debris. Finally, we run our seedlots through a fanning mill using various size screens to provide clean seeds. This year, we will collect around 6.8 million seeds from hundreds of plants in our nursery, many of them by using this method. This ensures that we capture seeds when they are ripe and protects them from loss. Our collection bags can also be used for wild collections for many other species that have rapid dispersal or present other problems for the seed collector.

REFERENCE

USDA NRCS. 2002. The PLANTS database, version 3.5. URL: http://plants.usda.gov (accessed 18 Aug 2003). Baton Rouge (LA): The National Plant Data Center.
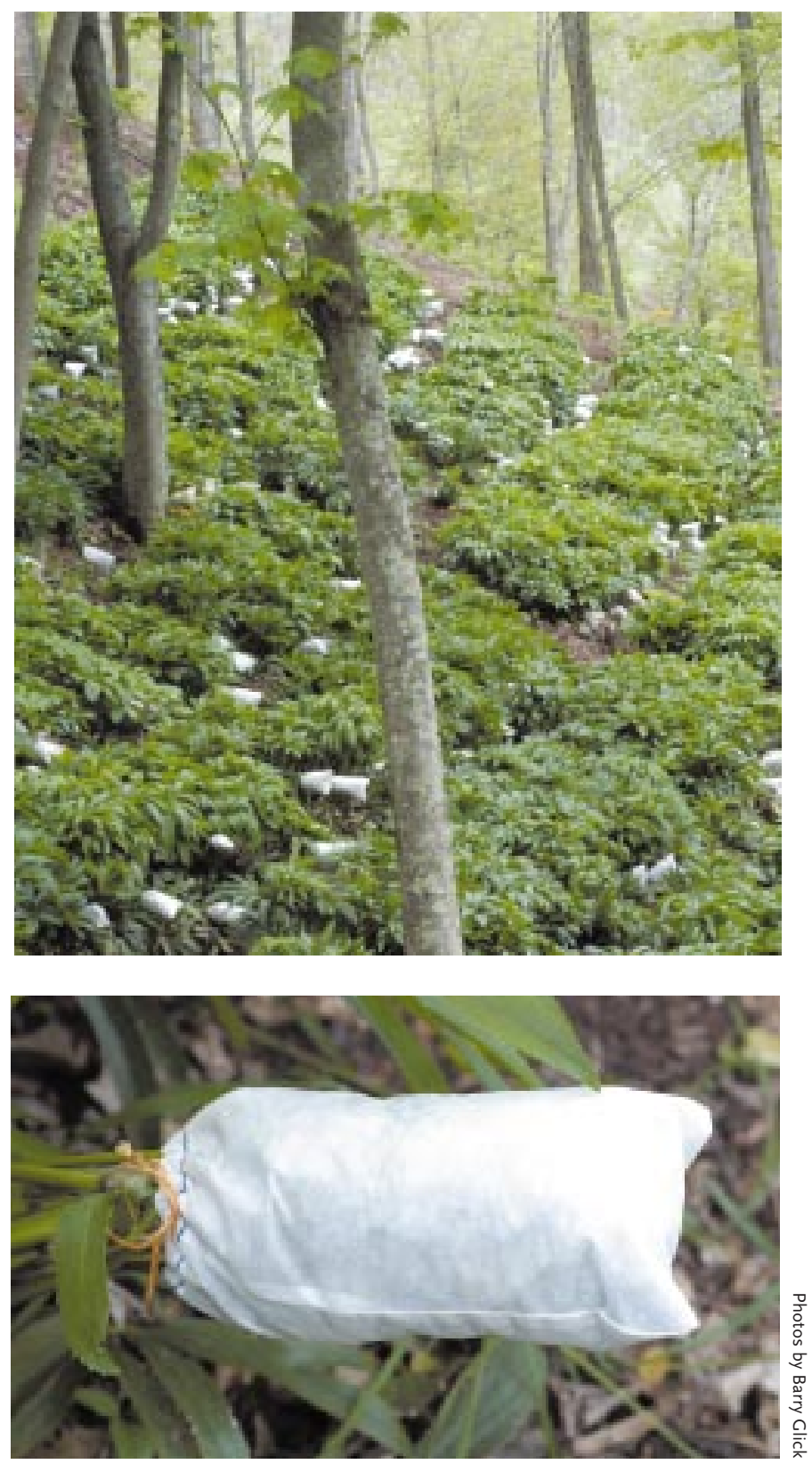

AUTHOR INFORMATION

Barry Glick

Sunshine Farms and Gardens

HC 67 Box 539 B

Renick, WV 24966

barry@sunfarm.com

www.sunfarm.com 


\section{RACQUETS, HOPPERS, AND FELT BOARDS- LOW-TECH DEVICES FOR PROCESSING SEEDS}

Scott Jensen |

A B STR A C T

In Utah, racquets and hoppers are used to collect small lots of long-leaf hawksbeard (Crepis acuminata Nutt. [Asteraceae]) and pale mountain dandelion (Agoseris glauca (Pursh) Raf. [Asteraceae]). These seedlots are often contaminated with squirreltail (Elymus elymoides (Raf.) Swezey [Poaceae]) and cheatgrass (Broumus tectorum L. [Poaceae]). We toss the mixed seeds at a large piece of plush felt-the composite seeds fall to a collection container but the appendages on the grasses stick to the felt.

KEY WORDS seed cleaning, Asteraceae, Crepis acuminata, long-leaf hawksbeard, Agoseris glauca, mountain dandelion, Poaceae, Elymus elymoides, squirreltail, Broumus tectorum, cheatgrass

\section{NOMENCLATURE} USDA NRCS (2002)

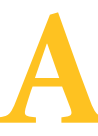

$\mathrm{t}$ the USDA Forest Service Shrub Sciences Laboratory, we collect the small-seeded composites (Asteraceae) long-leaf hawksbeard (Crepis acuminata Nutt.) and pale mountain dandelion (Agoseris glauca (Pursh) Raf.) by hand or with racquets and hoppers. Badminton racquets have a tight weave and are ideal for collecting lightweight seeds. Tennis racquets can be used on shrub species. In either case, we construct a hopper using cordura cloth sown onto a round frame (Figure 1). The cloth is attached to the frame so that the center has a drop down and seeds are not blown out of the hopper. When target species are in the open and higher in stature than surrounding vegetation, I find the racquet and hopper the fastest collection method. If the wind is blowing, I'll hand pick individual plants, immediately placing the seeds from each head into a bag.

Of course, some disparity in ripening time occurs among plants in a population. Because you may not be able to return to the site repeatedly to maximize a collection, we have experimented with collecting heads prior to full ripening. On the same day at the same site, long-leaf hawksbeard collected early (seed heads not open) had $40 \%$ viability while those collected with open heads yielded $61 \%$ viability. The effect of storage on viability of these 2 lots is unknown, but it is apparent that

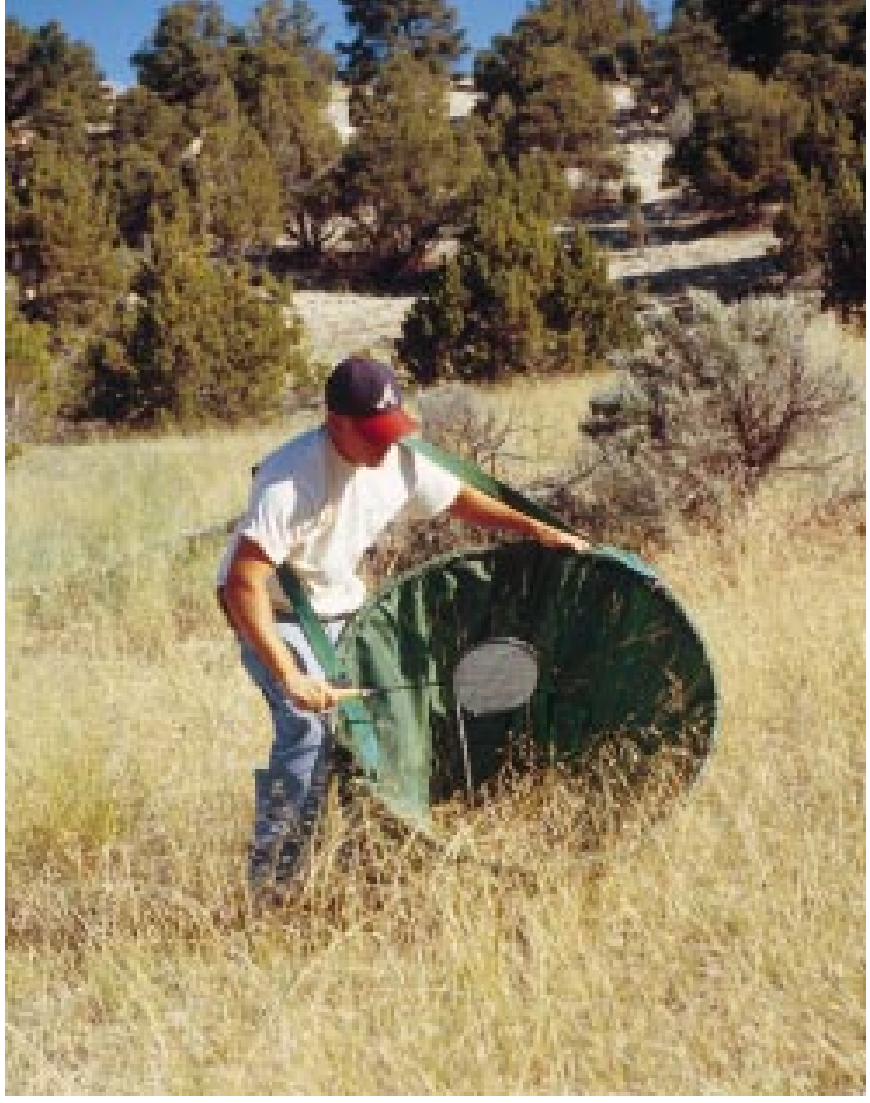

Figure 1. Collecting Asteraceae seeds with badminton racquet and a hopper made from cordura cloth sown onto a round frame.

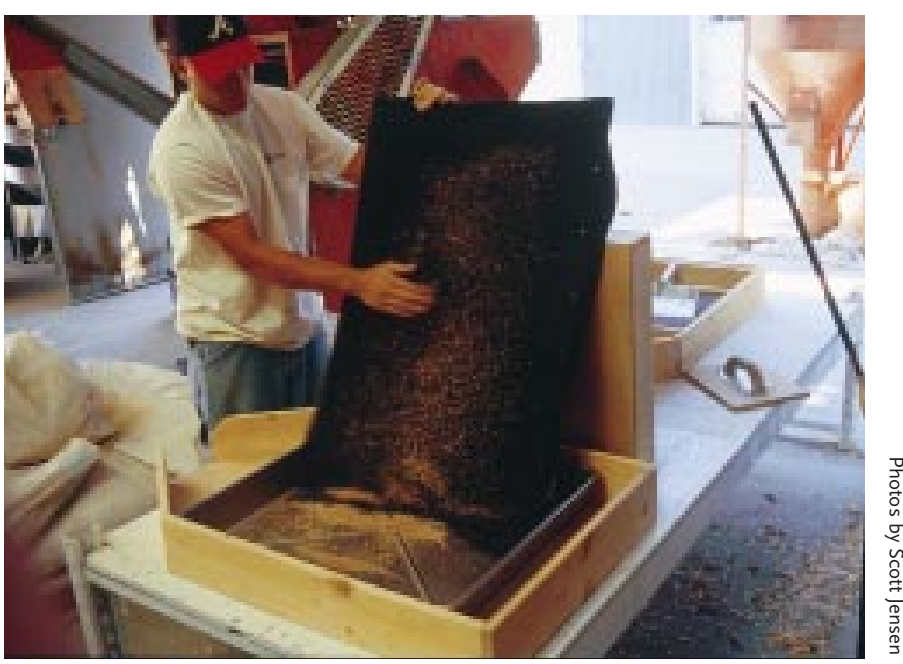

Figure 2. When tossed at a piece of felt, desired Asteraceae seeds fall into a collection pan but unwanted grass seeds, with their prickly appendages, are caught on the felt. 
closed head collections may yield some viable seeds. If the site is particularly windy a larger proportion of seeds may be harvested by early collection.

For small lot applications we have not found it necessary to remove the pappus from the achene, so cleaning is simply a matter of separating the chaff. Larger material can be picked out by hand or separated by a screen. Two grasses (Poaceae), squirreltail (Elymus elymoides (Raf.) Swezey) and cheatgrass (Broumus tectorum L.), are the most common seeds that contaminate our lots. We remove these species on our specially designed felt board. We simply drape a yard of plush felt material over a similarly sized plywood board, incline the board to a steep angle, and toss handfuls of seeds at the board. Most of the composite seeds rebound off the board and fall to the collection pan beneath. Shaking and tapping the board helps free any remaining composite seeds. Appendages on the grass seeds are caught on the loose weave of the felt (Figure 2). Different weaves may be best suited for different problems posed by various seed types. We now use the plush felt material whenever prickly seeded material needs to be separated from a seed lot.

\section{REF E R E N C E}

USDA NRCS. 2002. The PLANTS database, version 3.5. URL: http://plants.usda.gov (accessed 20 Jun 2003). Baton Rouge (LA): The National Plant Data Center.

\section{AUTHOR INFORMATION}

Scott Jensen

Botanist

USDA Forest Service

Shrub Sciences Laboratory

735 N 500 E

Provo, UT 84606-1865

sljenson@fs.fed.us
CLEANING GRASS SEEDS

Colleen Archibald and Craig Dremann |

A B STRACT

Wooden frames with hardware cloth provide an easy way to effectively pre-clean small lots of grass seeds in the field. We describe frames with 2 sizes of cloth used for western grass species.

KEY WORDS

Poaceae, Elymus, Bromus, Festuca, Koeleria, Deschampsia, wildrye, brome, fescue, prairie junegrass, hairgrass

NOM EN CLATUR E USDA NRCS (2002)

I $\mathrm{n}$ the field, seed heads of small lots of grass (Poaceae) can be harvested with scissors or small scythes and placed into paper bags, making sure to make a donut hole in the center of filled bags. This allows air to penetrate down to the bottom of the bag and prevents seeds from overheating in the field (Figure 1). Rather than bringing all of the high moisture content plant material back to the nursery for processing, drying, and cleaning, we find it useful to coarse screen the material in the field. For this screening, we constructed simple frames with hardware cloth, scrap lumber, and woodscrews.

We attached large diameter hardware cloth $(6.35 \mathrm{~mm}[0.25$ in] holes) to frames made from scrap wood $(66 \times 71 \mathrm{~cm}[26 \mathrm{x}$ 28 in] long). Small wooden flaps can be secured to the sides of the frames to give the frames some height. The hardware cloth is secured between wood frames with woodscrews. Once constructed, we used the frames (Figure 2) for cleaning directly after harvest in the field. It is essential to take a drop cloth and

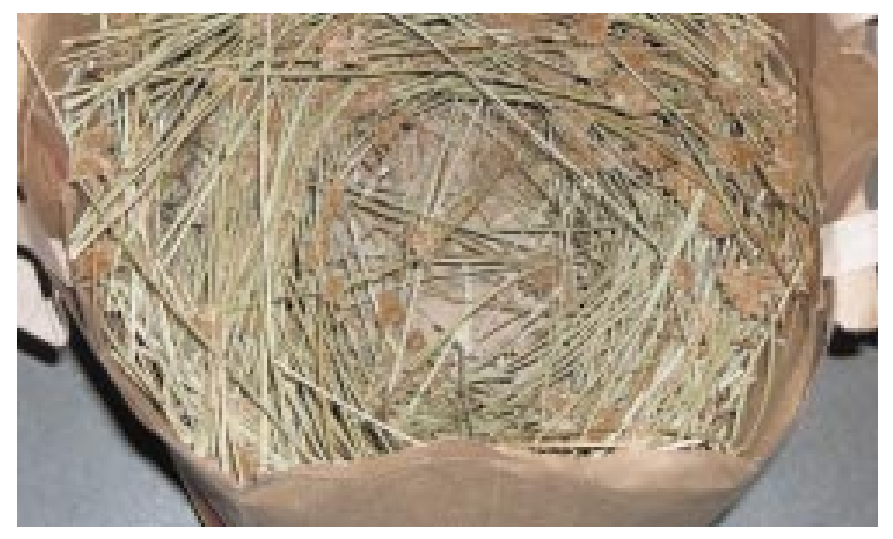

Figure 1. A donut hole in the collection bag allows air circulation and prevents seeds from overheating in the field. 


\title{
TUMBLING FOR SEED CLEANING AND CONDITIONING
}

\author{
David Dreesen |
}

A B STRACT

Small rock tumblers can be used to clean and condition seeds both in an aqueous and a dry mode. During the process, grit and gravel remove fruit pulp and abrade seed coats. Wet tumbling of seed aids imbibition, leaches watersoluble germination inhibitors, and may partially substitute for cold stratification for some shrub seed lots.

Figure 2. A wooden frame covered with hardware cloth makes an effective grass seed cleaning device.

paper bags, too. After collecting seed heads, we sit on the ground with the screen and rub the plant material vigorously a few times to dislodge the seeds from the inflorescences, which fall onto the drop cloth. We pour seeds into paper bags for transport back to the nursery.

Wildrye (Elymus spp. L.) and bromes (Bromus spp. L.) are species we commonly and easily pre-clean in the field with our screens. For smaller-seeded grass species, such as prairie junegrass (Koeleria macrantha (Ledeb.) J.A. Schultes), hairgrass (Deschampsia spp. Beauv.), and fescues (Festuca spp. L.), we use frames with smaller diameter hardware cloth (3.1 mm [0.125 in] holes).

We think you will be surprised how easily small lots of many species can be cleaned with this method, and how minimal the amount of chaff in the seed lot will be.

REFERENCE

USDA NRCS. 2002. The PLANTS database, version 3.5. URL: http://plants.usda.gov (accessed 20 Apr 2003). Baton Rouge (LA): The National Plant Data Center.

\section{AUTHOR INFORMATION}

Colleen Archibald, Biological Technician

USDA Forest Service | J Herbert Stone Nursery

2606 Old Stage Road | Central Point, OR 97502

carchibald@fs.fed.us

Craig Dremann, Co-Owner

The Reveg Edge

PO Box 609 | Redwood City, CA 94064 
time and can be separated using sieves and strong sprays of water. In addition, the wet tumbling thoroughly imbibes seeds and may leach out water soluble germination inhibitors. After cleaning and imbibition, seeds are typically cold stratified.

Dry tumbling to scarify legume seeds has been investigated (Bonner and others 1974; Dreesen and Harrington 1997). The rationale for dry tumbling is to avoid seed destruction that can readily occur with sulfuric acid, boiling water, and high energy impact mechanical scarification treatments. Dry tumbling is a slow process taking several days to a week, but we often use it when we have small seed lots we do not want to risk with other scarification treatments. The procedure uses carborundum grit (sold by rock tumbler dealers), pea gravel, and seeds. After tumbling, scarified seeds are separated from the grit and gravel with sieves. The grit can also be reused by washing the seed coat debris through a fine sieve or by floating off the debris and then drying the grit. Different size grits are available and we typically use fairly coarse material. Coarse grit size is still much smaller than most legume seeds, allowing the easy sieve separation of grit, seeds, and gravel.

Wet tumbling can be used for scarification if an abrasive (typically pea gravel) is incorporated in the seed and water slurry (Dreesen and others 2002). The force imparted to the grit by the tumbling gravel facilitates abrasion. Although this treatment method may result in some seed coat degradation, other effects may be more important, such as assuring complete imbibition in well-aerated water and the leaching of water soluble germination inhibitors in the seed coat. A typical treatment would involve wet tumbling for several days to a week with daily changes of water.

For a few species, wet tumbling may partially substitute for a cold stratification requirement. Two currant species (Ribes aureum Pursh and R. cereum Dougl. [Grossulariaceae]) and wolfberry (Lycium torreyii Gray [Solanaceae]) generally require 2 to 3 $\mathrm{m}$ of cold stratification to achieve acceptable germination. Wet tumbling followed by 1 to $2 \mathrm{wk}$ of storage in a warm moist environment has resulted in germination without cold stratification. The dry seeds of another important riparian species, redosier dogwood (Cornus sericea L. ssp. sericea [Cornaceae]), generally require $1 \mathrm{~h}$ scarification in concentrated sulfuric acid and then 2 to 3 mo of cold stratification for acceptable germination. Using fresh fruit with hydrated pulp, rapid germination has been achieved by wet tumbling the fruit with 1 to $2 \mathrm{~cm}$ ( 0.5 to $0.75 \mathrm{in}$ ) gravel. Most of the pulp is removed in the first day of tumbling and separated by screening and float/sink manipulations in water. After pulp removal, seeds are wet tumbled for several more days with daily water changes. The imbibed seed is then stored in a warm moist environment; germination starts in about 7 to $10 \mathrm{~d}$ and continues for several weeks. Although a limited number of species have been tested with wet tumbling for seed conditioning, additional species may benefit from this treatment.

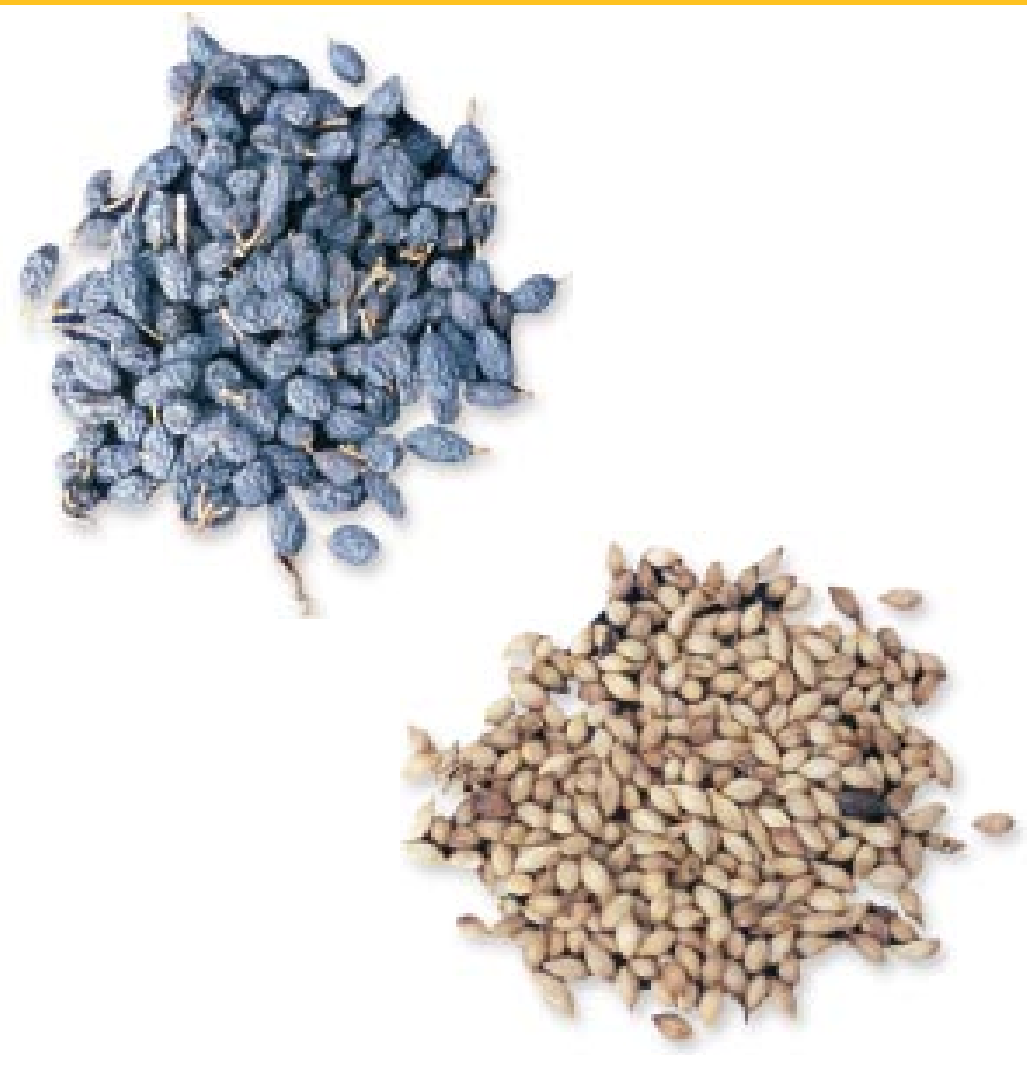

Figure 1. The pulp of naturally dehydrated fruits (top) of New Mexico olive can be removed using a rock tumbler, leaving extremely clean seeds (bottom).

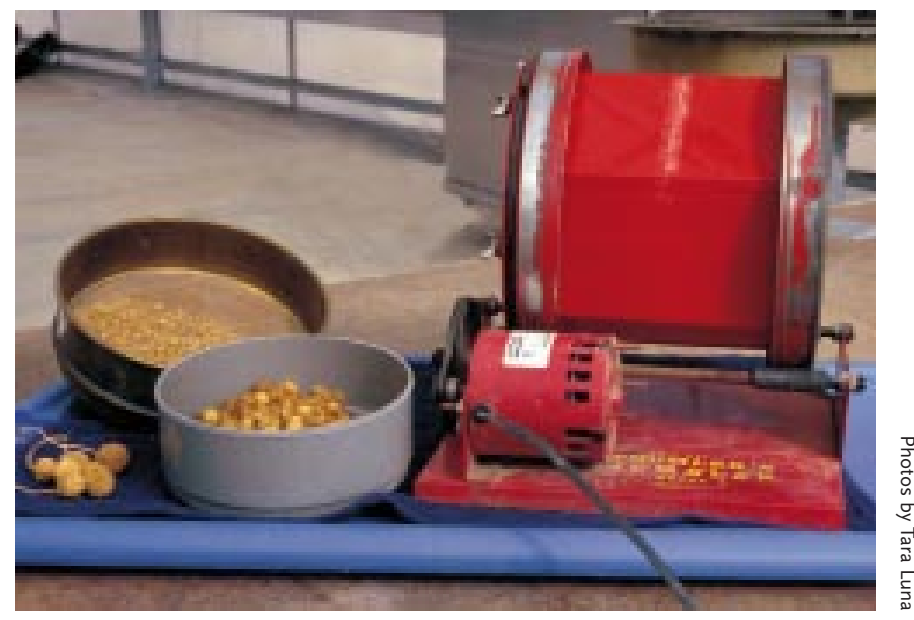

Figure 2. At Los Lunas Plant Materials Center, dry fruiting heads of Arizona sycamore, seen lower left, are crushed under water in a large pan. The hairs agglomerate into balls (gray sieve in foreground). A slurry of achenes and pea gravel are tumbled in the rock tumber to dislodge the hairs. Finally, the achenes, hairs, and pea gravel are separated with soil sieves with the cleaned achenes visible in the brass sieve (background). 


\section{LOW COST TOOLS FOR SEED COLLECTION AND SEED SOWING}

Bonner FT, McLemore BF, Barnett JP. 1974. Presowing treatment of seed to speed germination. In: Schopmeyer CS, technical coordinator. Seeds of woody plants in the United States. Washington (DC): USDA Forest Service. Agriculture Handbook No. 450. p 126-135.

Dreesen DR, Harrington JT. 1997. Propagation of native plants for restoration projects in the Southwestern U.S.—preliminary investigations. In: Landis TD; Thompson JR, technical coordinators. National proceedings, forest and conservation nursery associations. Portland (OR): USDA Forest Service, Pacific Northwest Research Station. General Technical Report PNW-GTR-419. p 77-88.

Dreesen DR, Harrington J, Subirge T, Stewart P, Fenchel G. 2002. Riparian restoration in the southwest: species selection, propagation, planting methods, and case studies. In: Dumroese RK; Riley LE; Landis TD, technical coordinators. National proceedings: forest and conservation nursery associations-1999, 2000, and 2001. Ogden (UT): USDA Forest Service Rocky Mountain Research Station. Proceedings RMRS-P-24. p 253-272.

USDA NRCS. 2002. The PLANTS database, version 3.5. URL: http://plants.usda.gov (accessed 10 Jun 2003). Baton Rouge (LA): The National Plant Data Center.

\section{AUTHOR INFORMATION}

David Dreesen

Horticulturist

USDA Natural Resources Conservation Service

Los Lunas Plant Materials Center

Los Lunas, NM 87031

David.Dreesen@nm.usda.gov
Dawn Thomas |

ABSTRACT

A modified $35-\mathrm{mm}$ film canister is a useful tool for controlled sowing of small-seeded native species, and a simple, metal, custom-made harvester makes for efficient collection of late-season fleshy fruits.

KEY WORDS

Salicaceae, Populus, Salix, Philadelphus lewisii, Hydrangeaceae, Carex, Schoenoplectus, Cyperaceae, Juncus, Juncaceae, Rosa woodsii, Rosaceae, Symphoricarpos albus, Caprifoliaceae

NOMENCLATURE USDA NRCS (2002)

n my nursery program, I find that simple, inexpensive tools often work well. Two tools that I use regularly are a 35-mm film canister with a hole punched in the lid, and a custom-made, "fingered," tin fruit harvester.

\section{FILM CANISTER FOR} ACCURATE SEED SOWING

I use a film canister to accurately sow small seeds. First, I measure the size of seeds of the species I intend to sow to get an idea of how large or small to make the hole in the film canister lid. Next, I heat the tip of a piece of wire and melt a hole in the center of the lid from the bottom side out. I found that if I melt the hole from the top inward, seeds will hang up on the plastic edges around the hole and will not shake through easily. I test the shaker to see how many seeds come through the lid by simply turning it over with 1 or 2 shakes. I modify the size of the opening on a new film canister lid based on the results.

For willows (Salix L.), quaking aspen (Populus tremuloides Michx.), and black cottonwood (Populus balsamifera ssp. trichocarpa (Torr. \& Gray ex Hook.) Brayshaw [Salicaceae]) seeds, I try for a hole of sufficient size to allow 2 seeds to easily fall through the opening per shake so that nursery workers do not have to vigorously shake the containers. By taking time to make the hole size accurate, I reduce the amount of seeds sown per container, the time it takes to sow the crop, and eliminate hours of thinning multiple germinants per container (Figure 1).

This method works well for other small-seeded species, such as Lewis' mockorange (Philadelphus lewisii Pursh 


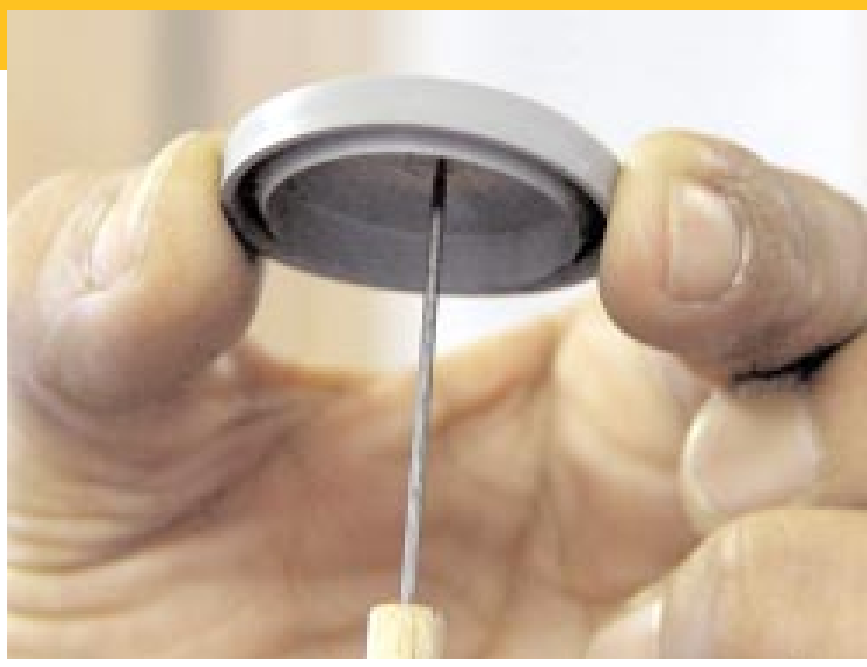

Figure 1. Melting a hole in film canister lid converts it into an inexpensive but effective device for sowing small seeds.

[Hydrangeaceae]) and for many wetland species, such as sedges (Carex L.), bulrushes (Schoenoplectus (Reichenb.) Palla [Cyperaceae]), and rushes (Juncus L. [Juncaceae]).

\section{CUSTOM-MADE TIN FRUIT HARVESTER}

I designed a metal fruit harvester out of tin so that we could efficiently harvest large quantities of late-season fleshy fruits, such as woods rose (Rosa woodsii Lindl. [Rosaceae]) and snowberry (Symphoricarpos albus (L.) Blake [Caprifoliaceae]). The end of the scoop has several metal fingers that are spaced so that when the fruit-bearing stems are combed through the fingers, the fruits are pulled off but the stems pass through the fingers undamaged. This creates an easy and debris-free harvest of fruits when used after leaf fall in late autumn. The tin fruit harvester can be made cheaply by any local sheet metal shop and customized for late season fruits in your area (Figure 2).

\section{AUTHOR INFORMATION}

\section{Dawn Thomas}

Nursery Manager

Salish-Kootenai Tribal College Native Plant Nursery

PO Box 70

Pablo, MT 59855

Dawn_Thomas@skc.edu

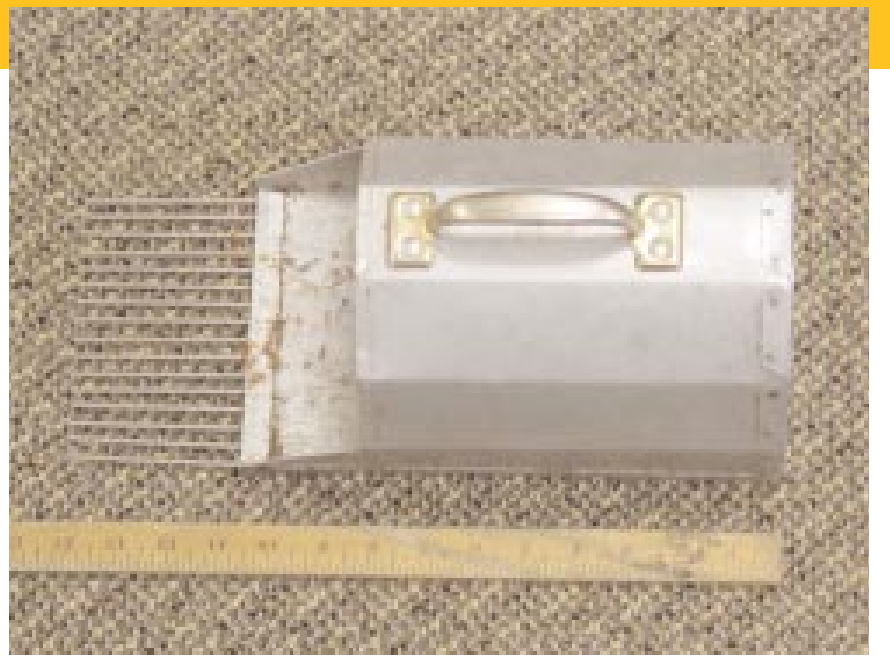

Figure 2. A custom-made metal harvester for collecting fruits.

REFERENCE

USDA NRCS. 2002. The PLANTS database, version 3.5. URL: http://plants. usda. gov (accessed 3 Dec 2003). Baton Rouge (LA): The National Plant Data Center.

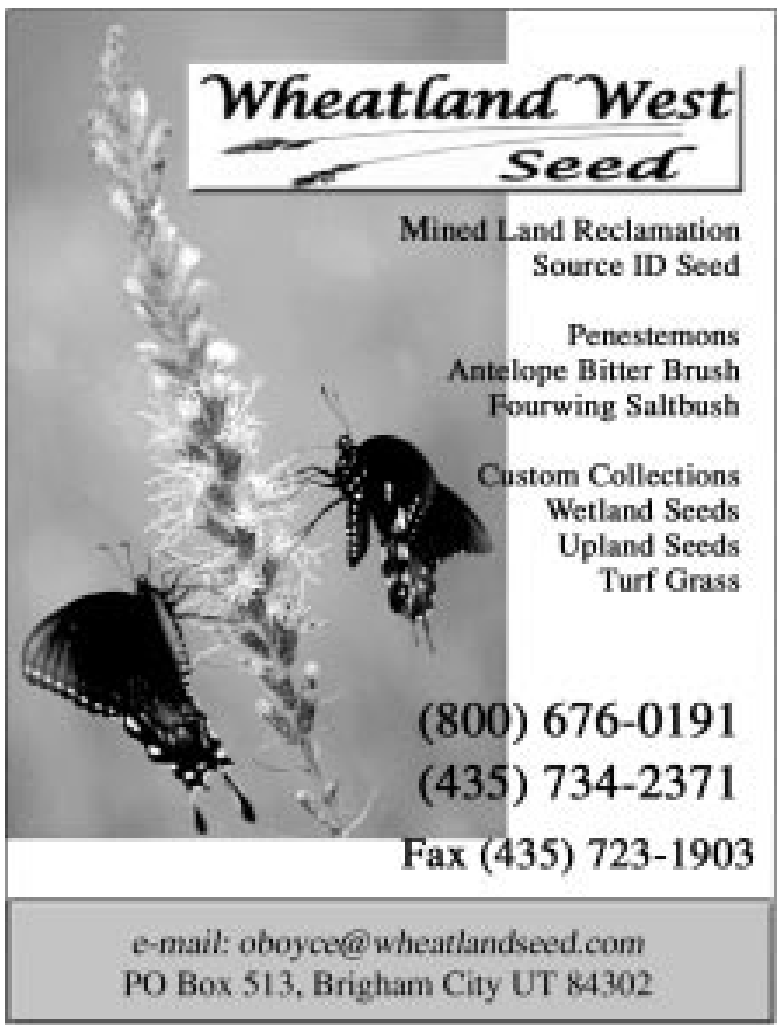

